\title{
Impoliteness and Computer-Mediated Discourse
}

\author{
Stephen Anurudu*, Grace Ochuko
}

English Studies Department, University of Port Harcourt, University of PMB 5323 Choba, East-West Rd, Port Harcourt, Nigeria

DOI: $10.36347 /$ sjahss.2020.v08i04.004

| Received: 30.03.2020 | Accepted: 06.04.2020 | Published: 14.04.2020

*Corresponding author: Stephen Anurudu

Abstract

Original Research Article

The emergence of internet-enabled communication has made computer-mediated discourse a daily routine nowadays. Consequent on this, the face of communication has changed a lot as regards acceptable behavior in communication. This paper examines impoliteness in computer-mediated discourse with particular focus on online comments on political articles in the Nigerian newspaper. Using Culpeper's (1996 and 2003) impoliteness strategies, the work X-rays the causes and types of impoliteness building on such notions as flaming and trolling as regards impoliteness. Findings revealed that impoliteness is not directed only at the content of the article but mostly at the person mentioned in the article, and the comments of the online users. The study also indicated that netizens exhibit a form of power because of the anonymity of the internet and display the same attitude found in face-to-face communication dispute in the real world but with a more intense emotiveness. In all, it is virtually impossible to inflame without being impolite. This study contributes to the growing literature on impoliteness focusing on the causes and types of impoliteness strategies in Nigerian online newspaper political discourse.

Keywords: Politeness, face, impoliteness strategy, flaming, trolling.

Copyright @ 2020: This is an open-access article distributed under the terms of the Creative Commons Attribution license which permits unrestricted use, distribution, and reproduction in any medium for non-commercial use (NonCommercial, or CC-BY-NC) provided the original author and source are credited.

\section{INTRODUCTION}

With the advent of Information Communication Technology (ICT), new methods of communication emerged. Computers, internet and smart phones are widespread devices that are currently used as medium of communication. These developments gave rise to a change in other fields such as discourse. Computer mediated discourse is a branch of computer mediated communication (CMC). CMC is a process in which human interaction occurs through one or more networked telecommunication systems. A CMC interaction occurs through various types of networking technology and software, including e-mail, internet, Instant Messaging (IM), Usenet and mailing list servers. Computer Mediated Discourse an offshoot of CMC refers to the communication produced by humans while transmitting message via networked computers. The prominent characteristic feature, especially of many text base CMC is anonymity that is, they are faceless and bodiless forms of interaction $[1,2]$.

Interaction via computer networks or communicative networking is a recent phenomenon which originated in the United States in the late 1960's to facilitate the transfer of computer programmes and data between remote computers in the interests of national defense. However, within a short time, the use of computers for interpersonal communication developed. Early scholars were confused as to how to classify this form of CMD. The notion they had was that CMD was "anonymous", "personal", "egalitarian", "fragmented" and "spoken-like", and they failed to classify the various uses of CMD" [3]. However, Herring [3] was able to classify CMD by looking closely at some research works in CMD. She identified "private e-mails, Listnet mailing lists, Usenet newsgroup, IRC and MUDs" (which) are social media that are technologically defined, each having their own unique histories and cultures of use". In the light of the discussion above, CMD is simply another medium of communication.

The notion of impoliteness emerged by way of contrast to politeness. Early studies on impoliteness [46] worked with Brown and Levinson [7] paradigm by mirroring politeness strategies with general impoliteness strategies. Thus, to fruitfully discuss impoliteness, it is pertinent to explicate politeness. In the discussion of politeness, the concept 'face' or 'face theory' has to be considered as well. Therefore, the review will take a look at these three phenomena namely face, politeness and impoliteness. 
Impoliteness and Computer Mediated Discourse

CMD has become another means of daily communication for so many people. The internet has become more than a source of information and entertainment. Net users establish and maintain close relationship with their online friends. As the communicative ability of the internet increases, many linguists and scholars are more interested in researching CMC strategies [8-11]. As CMD is an offshoot of $\mathrm{CMC}$, impoliteness strategies which apply to CMC can also be employed in CMD.

Sproull and Kiesler [12] states that "computer based communication technology creates a new forum for human communication, one whose rules are not like those of any other forum". Furthermore, Claridge [13, 11], states that Computer Mediated Communication (CMC), especially the web based public variety, has the potential to influence and partly transform the nature of public debate by uniting people with share values and goals in a common cause- regardless of their separation in space and time. Sproull and Kiesler [12] add that "electronic messages are often startlingly blunt, and electronic discussions can escalate rapidly into name calling and epithets, behavior that computer buffs call flaming".

In CMD, the forum has different rules compare to face-to-face communication. Electronic communication is either synchronous or asynchronous which sometimes makes turn taking redundant. Also, users have equal right than in face-to-face conversations, which is due to the anonymity of prestige and social status that are usually absent in CMD 14]. Thus, CMD offers a resourceful base for research on impoliteness as the amount of data is huge.

\section{The Concept of Face}

Face is equal or has the same meaning as public self-image [15]. Face is an important concept in the study of politeness and impoliteness. Face means "an image of a person's personality which is described in terms of permitted social elements" [16, 17]. According to Yule [15], face means someone's "emotional and social sense" which is hoped to be recognized by others. To Goffman [18], "face is the positive social value a person effectively claims for himself by the line others assume he has taken during a personal contact". He further explained that "face is like a persona which we present in a conversation". There is an unwritten norm that interlocutors maintain each other face needs. When one party or both involve in a conversation fail to meet their face needs, misunderstanding is bound to occur. Face is not static, that is, the situation determines what the interlocutors present to each other. Thus, face changes from 'situation to situation'.
Face within Brown and Levinson's framework is based on the interpretation of Goffman's definition [18]:

...the positive social value a person effectively claims for himself by the line others assume he has taken during a particular contact. Face is an image of selfdelineation in terms of approved social attributes-an image that others may share, as when a person makes a good showing for his profession or religion by making a good showing for himself.

There are basically two types of face needs namely positive and negative. Positive face needs is the need to look good, be likeable while negative face needs include the need to be free, have an open schedule and freedom from imposition by others. Brown and Levinson explained negative face as the want of every competent adult that his or her actions be unimpeded by others [19]. Positive face is the want of every adult that his or her wants be desirable to at least by some others. The duality of face does not represent a scalar morality between good or bad that is, positive and negative. Both are distinct sets of face wants that are individualized according to each person internalized desires [20].

Terkourafi [21] has gone even further to define face by dividing the notion of face in to two concepts, Face1 and Face2. Face2 is defined as, "[...] (first) the biological grounding of face in the dimension of approach versus withdrawal, and (secondly) the intentionality of face i.e. its directedness, or aboutness". Face 2 includes both positive and negative features and is universal. Terkourafi [21] states that, [...] Face2 cannot be an attribute of individuals in isolation. Individuals alone do not 'have' face and cannot 'gain' or 'lose' face. Rather, Face2 is grounded in the interactional dyad. Without another to whom they may be directed, face concerns cannot arise. The notion of Terkourafi's [21] Face2 arose from the theory of politeness 1 and politeness 2 by O'Driscoll [22], where politeness 1 is the notion of everyday politeness while politeness 2 is the linguistic and academic sense of why, when and how some expressions achieve social adequacy. Therefore, Face1 relies on politeness 1 or the layperson's perspective of politeness.

Goffman's [18] and Brown and Levinson's $[19,7]$ theories of face have been criticized for only taking into account the personal and individual scope of face. Spencer-Oatey [23] states that, "[...] face can be a group-based phenomenon, and apply to any group that a person is a member of and is concerned about". These groups can be for example one's family or larger groups that a person belongs to such as nationality or ethnic group. When face is a group-based phenomenon, it is referred to as social identity face. 
Furthermore, Brewer and Gardner [24] define three levels of self representation which are relevant to this study. They are,

- The personal self which refers to the individual level

- The relational self which refers to the interpersonal level

- The collective self which refers to the group level.

This shows that there are face threats that are aimed at the social identity face an interlocutor may have. Interlocutors have a choice to either save one another's face which is termed in face theory as face saving act or attack the other known as face threatening act (FFA).

Face threatening act is something that represents a threat to another's face (image) while face saving act is something or an utterance that lessens or does not contain a threat to another's face [15]. Brown and Levinson [7] also explain face-saving as when the person's face wants are met, that is, when an interlocutor tries to please his listeners or hearers by praising them even when they deserve to be scolded and face-threatening act as when the reverse occurs. Scholars have identified three factors that determine the weight of face-threatening act namely; power, rank and distance.

Power refers to the perceived power dynamics between speakers and hearers. The speaker or the hearer could be a superior, subordinate, or at about the same social level. Rank refers to the cultural ranking of the subject, that is, the degree of sensibility of the topic with a particular culture. For instance, one's religious belief is a very sensitive issue in Nigeria especially in the northern part of the country. Also, the current political and economic situation of the country makes every issue about politics and the economy crucial. Distance on the other hand refers to the amount of social distance between speakers and hearers, for instance, the hearer could be a closed friend or distant colleague or may have no direct relationship with the speaker.

\section{The Concept of Politeness}

Yule [15] states that "politeness is showing awareness of another person's face". Politeness was seen as a technical concept that explains motivations for why people adapt linguistic expressions in different situations when addressing different interlocutors. Politeness is a means which interlocutors use to mitigate the danger in conversational disharmony. According to Lakoff $[25,26]$ who is considered 'the mother of modern politeness theory, politeness is defined as a system of interpersonal relations designed to facilitate interaction by minimizing the potential for conflict and confrontation inherent in all human interchange. It is "conventionally interpretable subset of polite behaviour that is responsible for the smooth socio-communicative interaction and the consequent production of well-formed discourse without open social group characterized by elaborated speech codes".

From the various definitions, interlocutors try as much as possible to maintain harmony or concordance when interacting by taking care of the face presented by the listener or hearer. Politeness as a social factor is one of the important aspects of human communication. It is not inherent in human from birth but acquired with time through a formal or unwritten codes of socialization which are in most cases socioculturally and historically constructed. Politeness is about the strategic manipulation of language in the expedition of our conversational goals by saying what is considered as appropriate [27]. It is the "application of good manners and etiquettes in interactive and general communicative context" [28].

Politeness is anchored on two views; traditional which is theory driven and advocated by Lakoff [29], Brown and Levinson [7] etc, and the postmodern associated with the commonsense notion developed by Eelen [26], Mills [30], Watts [31] etc. Several theories of politeness such as Fraser and Nolen's [32], Leech's [33] politeness model, Lakoff's [25] politeness model, Spencer-Oatey's [34] politeness model, among others have been propounded from the two broad views. However, our focus will be on Brown and Levinson's [7] model of politeness as it relates to the framework of impoliteness for this study.

Brown and Levinson's theory of politeness is the most influential in the theory of politeness. They anchored their theory on the notion of face. They explain the nature of politeness and how it functions in interaction. Their claim is that face which could either be positive or negative, can be gained or lost in human communication. In order to save interaction from total collapse, they evolved five politeness strategies.

1. Bald on Record - entails performing an act in the most direct way possible, without concern for the hearer's face wants. In this case, the hearer's face wants are not threatened due to one of three factors that render the transactional nature of the message of greatest importance:

a) The urgency or importance of the utterance,

b) An utterance that strongly represents the hearer's interests, and,

c) When the speaker is superior enough to the hearer in terms of power.

2. Positive Politeness - addresses the positive face want of the hearer. In other words, the positive selfimage of the hearer is confirmed through acceptance of membership in a common group between speaker and hearer, or through confirmation that the hearer is accepted and liked by the speaker. 
3. Negative politeness - recognizes the hearer's desire for freedom of action. The attention to negative face is manifested through apologies for interruption, hedges, deference, or with other moves that satisfy the hearer's desire to "maintain claims of territory and selfdetermination."

4. Off Record Politeness - allows the intention of an act to be marked through indirectness therefore allowing the speaker to claim an alternative motive should the original intention be challenged by the hearer.

5. Don't do the FTA - prevents damage to the social relationship in instances where the desire of the speaker to carry-out the transactional elements of an FTA does not outweigh the perceived damaging effects of the interactional elements.

\section{The Concept of Impoliteness}

Many scholars have given various definitions of impoliteness. Goffman [18] refers to impoliteness as aggressive facework. It is "communicative strategies designed to attack face and thereby cause social conflict and disharmony" [27]. It can also be regarded as a situation where a speaker communicates face-attack intentionally, or when the hearer perceives and/or construct behavior as intentionally face-attacking, or a combination of both.

Face attack are "communicative acts perceived by members of a social community to be purposefully offensive" [35]. Impoliteness is how offence is communicated and received. It is not incidental face attack. It is not "caused inadvertently as a result of a person pursuing a particular cause of action". It is not a "by-product of an action that the offender carriers out in spite of its offensive consequence". It is not "face threat as a result of innocent action such as verbal gaffe". Impoliteness consists of face attacks that are "deliberately nasty, characterized by maliciousness and spite. It is "aggressive faceworks", a competitive mutilation and "scramble of another person's face in an attempt to look better at another expenses" $[35,16,36$, 37]. The perception of impoliteness rely on interactants interpretations in a given context to assess what is appropriate, and past incidents that may influence those interpretations [38].

Impoliteness phenomenon has been examined by a few studies than those studying politeness. Culpeper [4] states that "little works has been done on communicative strategies with the opposite orientation of attacking one's interlocutor and causing disharmony". He is among the linguist who advocated that power and intimacy are two contextual factors that increase vulnerability of face. Impoliteness is more likely to occur in situations where there is an imbalance of power. Culpeper's [4] analysis of impoliteness in an army training camp underlines how hierarchical power structure is strictly maintained and how recruits are subjected to face attack by sergeants without hitting back.

Mills [30] is another linguist who examined the issue of impoliteness. According to her, impoliteness is not the opposite of politeness or the absence of polite expressions. Impoliteness depends on a number of factors including S's (speaker's) intentions, the norms and the culture of the community of practice (CofP), and the context within which the interaction occurs. To her, assessing a specific speech act as impolite implies a threat to the hearer's face or a violation of the expected norms of the same specific CoFP. For instance, she argued that though swearing and directness are considered as signs of impoliteness, they can be justified if they are uttered by a male; however, they are considered rude if uttered by a female.

Therefore, the interpretation of any linguistic signal has to take into account contextual elements such as gender, age, social status, effects of participants' relationship, social norms prevalent in the studied society etcetera. Impoliteness is not inherent in any particular utterance. There is "no sentence inherently polite or impolite. We often take certain expressions to be impolite; it is not the expressions themselves but the conditions under which they are used that determine the judgment of impoliteness" [4].

Impoliteness cannot be fully explained through the former politeness models and superstrategies such as Brown and Levinson's [19, 7]. Brown and Levinson [7] have been criticized on their bald-on-record superstrategy mainly because it lacks explanation. Basically, bald on record refers to a communication situation where the interlocutors speak directly and unambiguously. In regards to Brown and Levinson's $[19,7]$ politeness theory, directness in interaction would be perceived as face threatening and therefore impolite. For example, Culpeper et al., [27] state that, "[...] it is precisely those utterances that have the directness of bald on record which are difficult to interpret as either polite, impolite, or something in between". Goffman [18] notes that there are three types of impoliteness: insults, disagreeing and 'unwitting' offences in his study. Culpeper et al., [27] point out that Goffman's [18] categorization of impoliteness may be helpful, but it is not all encompassing. However, Brown and Levinson's $[19,7]$ politeness frameworks have provided a useful point of departure for many theories on impoliteness.

Many impoliteness researchers agree that there exists a link between impoliteness and the politeness theory of Brown and Levinson [19, 7]. However, I will also take into account the point of view that impoliteness does not need to be intentional [27]. 
Impoliteness is a negative attitude towards specific behaviours occurring in specific contexts. It is sustained by expectations, desires and/or beliefs about social organization, including, in particular, how one person's or group's identities are mediated by others in interaction. Situated behaviours are viewed negatively when they conflict with how one expects them to be, how one wants them to be and/or how one thinks they ought to be. Such behaviours always have or are presumed to have emotional consequences for at least one participant, that is, they cause or are presumed to cause offence.

Various factors can exacerbate how offensive an impolite behaviour is taken to be, including for example whether one understands a behaviour to be strongly intentional or not. Culpeper's [39] definition takes into account the situational and contextual factors of impoliteness, and in addition to this, it does not over emphasize the connection between politeness and impoliteness. It is important to differentiate the notions of first order impoliteness (impoliteness1) and second order impoliteness (impoliteness2).

Researchers [40] note that when the discussion refers to the layperson's or participant's view of impoliteness, it is referred to as first order impoliteness. Second order impoliteness refers to the researcher's view of impoliteness and theories of impoliteness. With this distinction, it is made clear that the academic concept of impoliteness may not be the same as the layperson's view. The layperson's view has been studied through impoliteness metadiscourse by Culpeper [39, 41]. Impoliteness may come in various forms. Culpeper [42] mentions that many times the impoliteness is directed towards a person's negative face rather than the positive one. This is understandable as negative face relates more to actions and requests while positive face is more personal and interlocutors tend to be more aware of violating the other's positive face. In addition to this, Culpeper [41] notes that if a conversation has a positive beginning, the negative turn is perceived as more impolite even though to another person it may sound perfectly normal in another situation.

\section{Intention, Impoliteness and the Hearer}

Bousfield [43] claims that for an act of instrumental impoliteness to be considered "successful impoliteness, the intention of the speaker (or 'author') to 'offend' (threaten/damage face) must be understood by those in the receiver role" (p. 78). He further develops a series of four impoliteness distinctions that further elaborate upon speaker intentionality and hearer interpretation:

1. If the Speaker (or someone in the producer role) intends face-damage and the Hearer (or someone in a receiver role) perceives the Speaker's (Producer's) intention to damage face... then impoliteness is successfully conveyed.
2. If the Speaker/Producer intends face damage but the Hearer/Receiver fails to perceive the speaker's intent/any face-damage, then the attempt at impoliteness fails.

3. If the Speaker/Producer does not intent facedamage but the Hearer/Receiver fails to perceive the speaker's intent/Producer's utterance as being intentionally face damaging then this could be Accidental face-damage, which could be caused by one or more of the following: Rudeness; Insensitivity; Hypersensitivity; a clash of expectations; a cultural misunderstanding; misidentification of the Community of Practice or the Activity Type in which they are engaged; some combination of these, or some other hitherto unidentified means of inadvertently causing offence or of perceiving offence when none was intended.

4. If the Speaker/Producer does not intend facedamage but the Hearer/Receiver constructs the Speaker's/Producer's utterance as being unintentionally face damaging then this could be one of the following: Incidental or Accidental face-damage... which could be caused by one, or more of the following: Rudeness; Insensitivity; Hypersensitivity; a clash of expectations; a cultural misunderstanding; misidentification of the Community of Practice or Activity Type in which they are engaged; some combination of these, or some hitherto unidentified means of inadvertently causing offense or of perceiving offense when none was intended (p.72-73).

Culpeper [39] further conceptualizes intentionality as being scalar in nature in that if a hearer understands an act to be intentional, it magnifies the level of offence received by the hearer or addressee. Thus, an utterance produced by a speaker who truly intends an utterance to be impolite is much more offensive to a hearer than an utterance that was not intended as impolite. Culpeper's [39] formalism also seems to view intentionality of the speaker in away more akin to Bousfield. Bousfield in particular believes that, in most cases, intentionality cannot be gleaned from the speaker's utterance alone, as one cannot peep into the mind of the individual responsible for an utterance. In effect, the researcher is only able to look at the chain of cause-and-effect that plays out between a speaker and a hearer. By this mode of thinking, one can only truly disambiguate a speaker's intention (as objective researchers) when an act of impoliteness is bare-faced and explicit. The intentions behind implicit acts such as sarcasm (or trolling, in this thesis) are likewise terribly difficult to reconstruct, as the speaker can disavow any intention of impoliteness should the hearer request clarification.

\section{How to detect an (IM) polite Utterance?}

Culpeper [41] notes that impoliteness "[...] is in the eye of the beholder". An utterance or incident in a certain situation or context may be perceived as 
impolite by one member but not by another member of a conversation. The emphasis should therefore be put on the context of the utterance, not totally on the linguistic form it actually takes. Furthermore, as mentioned above impoliteness does not need to be intentional [41]. There are other aspects that come to play when an utterance is interpreted as being impolite. Impoliteness depends on the contextual interpretation that the interlocutors make in the contextual situation. These judgments can be of the social status, age, social relation and role of the other and group membership. It is important to note that different groups have different value systems. This also can affect an individual's perceptions of what is the socially acceptable behavior in communicative situations.

Impoliteness is in many ways connected with power relations that are asymmetrical [43, 42]. In asymmetrical power relationships, impoliteness can be expected from the participant in the communicative situation who is higher ranked in power rather than the participant of lower rank. However, this does not rule out the possibility of impolite actions appearing from the lower ranked participant. In a situation where the lower ranked participant expresses an action of impoliteness reasons may vary. For example school children may use impoliteness in certain situations as a means to be perceived as one of the "cool kids" [41]. Most likely in this kind of situation, the goal is to gain respect or improve status within a social group. However, this is not the case in CMD as the ranks of users are not always obvious, relevant or respected.

\section{THEORETICAL FRAMEWORK}

This research adopts Culpeper's [4, 36] impoliteness strategies. Culpeper's impoliteness framework is classified into; bald on record impoliteness, positive impoliteness, negative impoliteness, sarcasm and withhold politeness. Besides intentionality, each type of impoliteness strategy has its specific linguistic realization.

Bald on record impoliteness is a face threatening act that can be realized through direct, clear and unambiguous statement or questions in situations where the recipient's face is at stake. Positive impoliteness is the strategy which is intended to attack the recipient's positive face. It is used to attack someone's face who wants to be acknowledged as a part of the society. It is realized in the following forms

1. Disassociating from the other,

2. Ignore or snub the other

3. Exclude the other from the activity

4. Be disinterested

5. Use inappropriate identity markers

6. Use obscure or secretive language

7. Seek disagreement

8. Use taboo words

9. Make the other feel uncomfortable

10. Calling the other names [4].
Negative impoliteness is used to damage the addressee's negative face wants. Negative face want is "the want of every 'competent adult member' that his actions be unimpeded by others" [7]. This involves such areas as avoiding imposing on others, wanting to complete actions without interference from others, expressing deference to others and expecting respect from others. It is realized in form of;

1. Condescending, scorning, or ridiculing,

2. Associating the other with a negative aspect, put the other's indebtedness on record

3. Invading the other's space.

4. Frighten [4].

Sarcasm or mock politeness is realized in form of politeness strategies that are obviously insincere. Withhold politeness on the other hand is the absence of politeness work where it would be expected. It can be realized in form of being silent and failing to thank.

In 2005, Culpeper moves away from Brown and Levinson [7] in terms of replacing the negative/positive dichotomy. He proposes the following attacks;

1. Attacks on quality

2. Attacks on social identity face

3. Attacks on equity rights

4. Attacks on association rights [44, 45].

Culpeper et al., [27] had earlier explained these attacks as not different from Culpeper [4]. Quality face is the desire to be evaluated positively in terms of personal qualities and the impoliteness strategy is realized when the attack is directed at the appearance and the other's ability to work. Social identity face is the desire for acknowledgement of social identities or roles and the impoliteness strategy is realized through condescending, scorn or ridicule. Equity rights is the belief that we are entitled to be treated fairly by others and the impoliteness strategy is realized through threatening to hinder or block the other physically or linguistically, challenge the other or impose on the other. Association right is the belief that we are entitled to associate with others in accordance with the type of relationship and the impoliteness strategy is realized through ignoring or snubbing the other and dissociating from the other.

\section{METHODOLOGY}

For this study, ten articles from both the Vanguard and the Punch newspapers were selected. Fifty comments which fit into impoliteness strategies based on Culpeper framework were selected. To get access to the forum is not difficult as anybody who reads the articles online can see the comments at the end of the articles. For this study, the Punch and the Vanguard were chosen as the newspapers where data would be collected. These newspapers were chosen as part of the study as they have more than hundred of registered online readers who comment in the 
newspapers online forum 'Disqus'. Furthermore, the commentators can comment on these articles via other social media such as Twitter and Facebook and the data on these articles are overwhelming, including being impolite. The first step taken in collecting data was to open the online site of the newspapers. After browsing through the articles in the headings politics and business and reading some of them as well as the comments made by online readers, the following articles were chosen;

"Wada Accuses Buhari of Playing Politics with Bailout fund" October 26, 2015.

"FG keeps Mum as LPG, Kerosene, Diesel Prices Soar", July 2, 2016

"IGP Arase Again warns Pro-Biafra

Protesters" November 8, 2015

"365 days of Buhari: His five key achievements" May 29, 2016

"Presidency Kicks as Saraki Says Cabal has Hijacked Buhari Govt"

"Saraki Displays Arithmetic Skills" November 7, 2015

The data collected consist of eighty comments from different articles from the Vanguard and Punch newspaper and they are analyzed based on Culpeper's $[4,27,36]$ theoretical framework. There are four types of impoliteness strategies found in my data and they are addressed to either the subject or persona of the article, the journalist, the content or other users (netizens). The impoliteness strategies are bald on record impoliteness, positive impoliteness, negative impoliteness and sarcasm or mock impoliteness.

\section{Bald on Record Impoliteness Strategy}

This strategy is used by the speaker to attack the recipient's face in a direct, clear, unambiguous and concise manner in situations where face is not irrelevant [4]. Bald on record impoliteness is employed by the speakers of the comments below which are on the article 'FG keeps mum as LPG, Kerosene, diesel prices soar' by Michael Eboh

- Trappe - This where we are, a government without vision, without direction, fantastically incompetent, 419 government who obtained power through false promises. The lies and propaganda has expired, they are faltering and faltering, confused as they can be. I pity APC/ Buhari fans for what they are going through, disappointment upon disappointments, they can hardly provide for their families as there take home pay can no longer take them home, the change they shouted is now big chain. what a pity, but "when the mind is blind, the brain, the eyes all become useless" just like book haram members, almajari;s alayes...........

As earlier explained, bald on record impoliteness is a direct, clear, concise and unambiguous way of stating ones opinion where the face of the receiver is not irrelevant. Trappe gives his definition of what he thinks the present administration is and how their previous tactics have failed them. He called the government 'without vision, direction, fantastically incompetent'. He also expresses his feelings without trying to mitigate his words towards those who had faith in APC and their current predicament. His description of the present government as 'without vision, without direction, fantastically incompetent' could have been alleviated but his intention to be impolite prevented mitigation where mincing of words is possible.

- Ejeta - The hardships continues and the government looks on helplessly. I bought gas recently for N4200 and kerosene for N190 per litre at the filling station. Meanwhile, the Delta Government has not paid May and June salaries for staff of the University - DELSU.

Again, speaker (2) described the position of the government who has the means to alleviate the sufferings going on as 'look on helplessly'. This would not have been regarded as impolite. However, when the intention of the speaker is put to test together with the second part of his comment, you will understand while it is regarded as bald on record impoliteness. The speaker itemizes the difference in commodities and mentioned how workers have not been paid for two months. This obviously shows that the helplessness he described is not only associated with the hike in the prices of commodities but with the act of governance of the present government.

- Pozoh2 - The economy is worse off than 2 years ago. This is the price Nigerians have to pay for been gullible and having their brains up side (upside) down. The politicians, leaders and their families continue to enjoy while the gullible masses will suffer the brunt. The leaders are not prepared to make sacrifices for the poor

Speaker (3) did not just state his opinion but compares the economy to 2 years ago which according to him was better than now. He associated the economic situation to the 'political mistake' make by 'gullible' Nigerians and categorically state that the leaders are not affected by the economic challenges that the populace are suffering. To him, the ruling party should not have been elected to be at the helm of affairs of the nation.

- Progressive1 - You are a big liar when gej was using dollars to campaign then did you raise any alarm then think twice before making unnecessary comment on here

In his reply to a comment by another 'netizen' (Pozoh2) speaker (4) shifted from the content of the article and attacks the speaker who did not speak favourably about the current government. He unambiguously stated that PDP is the cause of the current suffering of the masses. The present economic 
situation would have boosted the quality face of PDP though painful for the populaces. However, with more comments like that of speaker (4) who deliberately wants to shift the blame to PDP, the quality face of PDP has been attacked.

- $\quad$ Oyimafa - You must be a twarth, agbero. stop politicizing national issues to avoid national disintegration...

- In his response to speaker (4), speaker (5) called (4) a 'twarth (taut), agbero'. He obviously attacks (4's) face as he instructs him to 'stop politicizing national issues'. Speaker (4) has every right to express his opinion but speaker (5) feels (4) was out of line and took it as his responsibility to correct him.

- Just2s - Pointless, almost annoying, this is what sets us apart from advance countries, poor analysis of issues. Instead of looking for answers 2 what $\mathrm{u}$ don't understand u're fanning.

Speaker (6) comment is directed at the journalist who wrote the article. He considers the content to be 'pointless' and 'almost annoying'. His view of the article is something which only a journalist in a developing country like Nigeria will write. This is an attack on the quality face of the journalist as it means he (journalist) did not discharge his duty appropriately.

\section{Positive Impoliteness Strategy}

1. Culpeper [4] describes positive impoliteness as the strategy which attacks the recipients positive face. It is realized in ten designs as itemized in the theoretical framework. The following comments on the article IGP Arase Again Warns Pro-Biafra Protesters clearly portray positive impoliteness.

- Kingsley Hans - Imagine how stupid Nigeria is .... His (how) stupid their forces are they foolishly left bokoharam that are killing innocent Nigerians and decided to go after a harmless set of people who are peacefully agitating for their rights... no wonder NK (UK) called the country zoo.

- Baba Dabai - Just bcox Buhari is the president right? If u can't bis(be) naija any more, den pack nf (and) relocate to Ghana...... Animals.

- Daniel Dickson - See who is calling others animal, Lol, u know if we get Biafra, hunger will kill $\mathrm{u}, . . .$. we are not cowards like you.

These three speakers performed the positive impoliteness strategy. Han's seek disagreement in reaction to IGP Arase warnings to pro-biafra protesters. Han's attack by calling his (IGP) action as well as the force as stupid and use the word 'zoo' to describe Nigeria. He employs no mitigating devices to soften his disagreement. This is in support of Bousfield's [43] definition of impoliteness as communicative acts which are "unmitigated in contexts where mitigation is required".

Baba Dabai hit back with a counter disagreement in his bid to defend the president as he believes the protesters are fighting because "Buhari is the president". He employs name calling "animals". Dickson retaliates with negative and positive impoliteness strategies. He scorns Dubai "see who is calling others animals, lol(laughter)" and in turn use the word "cowards" to describe the group represented by Dabai.

Similarly, in example (5), disagreements are sought by the commentators over sequential turns and are oriented towards attacking face.

- Prince Gozel - It's too late IGP you can't stop the sun from raisen

- Deltavoice - See Igbo English *Spits*

- Nnamendotsam - Little slave, we can see your Queen's English.

- Sting Zoo - "see Igbo English" is this good English” Free education crap! Spit! Spit!, spit!, spit!

- Chekwube - Goat, note a lot of English people cannot be able to read nor be able to put their words in writing, so shut up your trap.

- nwa-Africa-That proves that only the illiterate are supporting terrorist gay Nnamdi Kanu.

The occurrence of disagreements and counter disagreement in the above example involve employing several designs positive impoliteness strategy. The participants, speakers (3), (4) and (5) are defending speaker (1) their kinsman by attacking speaker' (2) face. (3), (4) and (5) realized their disagreement by using name calling. (3) used 'little slave', (4) used 'free education crap' and (5) 'goat' all to attack (2) face by directly asserting that these inappropriate identify markers are what (2) is. It is clear that such exchange of disagreeing turns result in communication disharmony. Speaker (6) takes the disagreement back to the discussion which led to it by concluding that their attack on speaker (2) is a proof that "only the illiterates" are supporting Nnami kanu who he described as 'gay terrorist'.

\section{Negative Impoliteness}

Negative impoliteness is the strategy which is design to attack the negative face want of the recipient [4]. Negative impoliteness has four designs namely; condescending or scorning or ridiculing, invading the other space, frighten and associating the other with a negative aspect, put the other's indebtedness on record. The comments of the following speakers on the article '365 days of Buhari: His five key achievements' by Levinus Nwabughiogu, shows how they employ negative impoliteness.

- Bestmen - Which achievement? The man is cursed! With him as a president, Nigeria is in 
bondage. He practically has no basic human brain to start with. The only thing that goes up in his membrane is bloodshed and more bloodshed!

Without looking critically at the content of the article and the context in which the achievements of the president were outlined, one will have assumed that the speaker (Bestmen) actually is ignorant of the topic which idyllically he was supposed to have read before commenting. He started with a question which analyzed in isolation seems he seeks for information from the other users. However, his other sentences explain the true meaning of the question which is to ridicule the achievements of the president. Again, he attacked the equity and the social identity face of the president as he (Bestmen) sees the president's activity as a curse and that which has placed the nation in the current predicament. He invaded the president's privacy as he supposed that only bloodshed runs in the 'membrane' of the president. The commenter acted impolitely not only because of the context of the article but also because it was directed at the number one citizen of the nation.

- DonGray1 - The foreign trip where he went to sell Nigeria out as a poor and corrupt country!!!!

Furthermore, speaker (2) reduced the economic benefits accrued to the foreign trip of the president as the poor presentation of Nigeria to the outside world. It is obvious that the speaker is being sarcastic and also angry at some other statements which the president may have made rather than on the content of the article in question.

- Milosavagemilo -Nigerian elites and leaders are a very big joke completely incompetent

Speaker (3) seems to have digressed but in fact, he related the article to all leaders including the subject of the article and sees the all important achievements as a big joke performed by an incompetent leader.

- Control112 - Ordering d implementation of d UNEP report, a job dat has not been done is been listed as part of archivement (achievement)......very sick

One way in which negative impoliteness is performed is to put the others indebted on record which speaker (5) did. The case would have been different if he had just stated that the mentioned achievement has not been executed but ending with 'very sick' is an attack on the equity right of the president.

- Oyedun - One year of wasteful, no concrete or tangible achievement......no economic direction! Democracy day like morning day! What a shame!
One predominant way in which various online commentators perform negative impoliteness is to be disdainful. This speaker regards the one year service of the president as wasteful and all the achievements mentioned as vague because to him, the current government has no 'economic direction'.

- TTLord - Off (of) all that have just been stated, Buhari is -(minus) 0.That's to say nothing good comes or will ever come from him.

Netizens can assume any position when they are communicating because physical presence and societal norms which control the choice of words and actions in face-to-face communication could be completely ignored. Speaker (7) plays the role of a teacher as he scores Buhari's achievement (- 0) and concluded that nothing positive will ever come from the government. He equated the mentioned achievements to minus nothing and extended his analysis to include the years which the government still has to serve.

- Orderly - Buhari's democracy day speech this morning is empty. He failed to address $d$ unimaginable hardship on d land. Speech full of futuristic promises that will be denied just like campaign promises of APC. Much emphasis on Niger delta avengers but did not say a word on killer herdsmen who are his kinsmen. Is he supporting them? TOO BAD.

What a slap! How can the speech of the number one person in the nation on a very important day in history be 'empty'. He (Orderly) feels that the most important issues were not addressed by the president and the president is being biased because of ethnic difference between the Niger delta Avengers and the herdsmen who happened to be from the same region (North) with the president. This is to associate the president with a negative aspect and twist the speech of the president to achieve the point he wants to convey.

- Ace102 - On the scale of 20, I score buhari's first year in office 1. Don't argue, he has not done well. Nigeria needs d mercy of God.

Speaker (9) also decided to give a score card to the president which is as poor as 1 out of 20 . It seems like speaker (7) the outlined achievements discussed in the article are below the expectation of these speakers.

- Marcus Ijele - my heart bleeds for my SS and SE quashi Governors. They are lame docks. Their reasons for fear, I am yet to know. Even those of them in the Senate, except Leo Ogor and Enyinnaya Aberibe, non (none) of the SS and SE Senators can speak with some level of boldness. It is a shame. Some are even volunteering to lead mumuhari and his stupid Buratai or whatever to where they can find the militants. Shame. 
Just as different aspect of a speech may interest different readers and listeners in a face-to-face communication and their reactions cannot be predicted, so are the comments of some net users. The concern of this commenter is not the achievements which others declared insubstantial but the attitude of the SS and SE governors and senators which to him is pathetic. He ridicules the president's tactics and the military as well as the help of the governors to arrest the Avengers. In fact, the speaker also employed positive impoliteness as he called the governors 'lame dock', the president 'mumuhari and Buratai 'stupid' and bald on record impoliteness, 'it is a shame'.

- Emma-Mabe yanze! - Buhari's scorecard is a disgrace to the collective efforts of ordinary Nigerians who work hard day and night, only to be complicated by a Clueless, Certificateless Perjurer called Muhammadu Buhari....

Again, speaker (10) described the much explained achievements of the government as a 'disgrace' when compared to the hard work of the masses who have less result because the present govrnment has no direction. He attacks the face of the president as he describes him as a 'clueless, certificateless perjurer'.

\section{Sarcasm or Mock Impoliteness}

The third impoliteness strategy found in my data is that of using sarcasm or mock politeness to attack the face of the subject in the article or the content. Sarcasm is insincere politeness strategy to intentionally offend others. See the following examples from the article 'Saraki Displays Arithmetic Skills':

*Amen - ... If Saraki was smart, he would delay the composition of the senate committee. ...... take it, no going back on CCT trial, he will have to head the senate from Kuje prison or Kirikiri prison.

*Itenebe Valentine - Loizzxxxx, You are too funny .... Saraki is not going to any prison ..... even if he will go to prison, it's not that Kuje own loizzx

*Iyaro - Please don't take Amen serious he is a comedian. APC government .... Is fighting corruption in the pages of newspaper and barking as toothless dogs.

*Osa law - Go and sleep please who is taking Saraki to Kuje prison, you?

*Akeebaba - If you don't want Saraki to go to prison, can't you volunteer to replace him? He will pay you handsomely for it, $\mathrm{Na}$ business deal, no be so Osa law.

In the above example, speaker (1) mocks Saraki's formation of the senate committee by using the clause "if Saraki was smart". To him, it was a foolish step but he did not state so explicitly. He makes trivial the condition of prison life as he asserts that Saraki will head the senate from the prison. Speaker (2) extends the sarcasm as he rephrased S(1) utterance "even if he will go to prison, it is not Kuje own" and ended it with laughter "loizzx". Speaker (3) however, counters speaker (1) through a mock politeness strategy by being sarcastic about Amen's claim although he extends his to include APC whom he noted fights corruption on the pages of newspaper. Speaker (4) in support of speaker (3) also employs mock impoliteness strategy as he advises (1) to "go and sleep" while he asks a rhetorical question to engage (1) in the conversation. Speaker (5) picks up the conversation and in response to (4), employs sarcasm to answer S's (4) question in form of a question. "If you don't want Saraki to go to prison, can't you volunteer to replace him? He will pay you handsomely?

The technique of asking rhetorical questions is used insincerely in the above example, because $S$ (4) is trying to mock $S$ (1). In the same turn $S$ (5) in a sarcastic manner provides an answer to deliberately damage $S$ (4) face.

\section{DISCUSSION OF FINDINGS}

The current study examined online comments on political articles in the Vanguard and Punch newspapers. The main focus was to investigate the pragmatic use of impoliteness and their linguistic realization in English. The analyses suggested and revealed a form of power exercise by the commentators as a result of the veil of the internet. While Culpeper's analysis of army training camp underlined the role play by hierarchical power in impoliteness, these commentators have linguistic power or absolute freedom of expression as anyone can conveniently comment from their safe abode in wherever they are in the world. While difference in rank could prevent a lower rank speaker not to be impolite to his superior or a person of high rank, this is completely lost in online comments as commentators boldly expressed themselves without considering the position of the recipient. This is why a citizen can change the name of his president to 'mumuhari, call the senate president and his deputy 'criminals' and the whole governor of South-South and South East 'lame dock'.

Despite the technological distance of users, ethnic affinity and a natural tendency to defend ones root at play in the real world was also maintained in virtual communities. This accounted for the attack on 'Deltavoice' when he mocked 'Prince Gozel' in his comment "see Igbo English". Ethnic affinity accounted for 'Baba Dabai's' defense of Buhari as he saw proBiafra protest as a personal attack on the president. Also, it accounted for the impolite comments directed at the deputy senate president. In addition, the use of abusive words to reply or counter impolite remarks is another similarity between online and face-to-face dispute in the real world. The analyses revealed that 'netizens' are real people who transfer or display real life attitude online even though it is more intense than 
face-to-face communication. The study also showed the use of abbreviations which are not permitted in Standard English language. This could be as a result of the medium of expression. Some of these abbreviations are complicated as the meaning is not obvious from the form. However, it seems the virtual community members are familiar with them as they still interact freely. It also reveals the easy at which netizens coin words which may only be applicable in CMD in order to buttress their points, for example, 'certificateless', 'mumuhari', 'PDPigs'. Repetition of words seems to have the function of expressing emotions online and the use of simple and correct English despite the customized abbreviation. This implies that a new form of English is emerging in and from Computer Mediated Discourse. However, members try to obey the rules of syntax and semantics and a breach could lead to disagreement. This accounted for one of the directions of impoliteness noted in this study. The study suggested that the cause of impoliteness is not only because of the anonymity of the net but the disappointment of the speaker(s) at the receiver of the attack. The net sometimes is just a convenient outlet to express what netizens feel.

Finally, Impoliteness in online comments on political articles in the Nigerian newspapers occurs at three levels:

- Impoliteness directed at the content of the article

- Impoliteness directed at the persona in the article

- And impoliteness directed at a commentator as a result of his comment.

\section{CONCLUSIONS}

Based on the discussion and findings on the phenomena of impoliteness in online comments on political articles in the Nigerian newspaper, the researcher draws the following conclusions presented below. Bald on record impoliteness, negative impoliteness and positive impoliteness were mostly adopted by netizens. They want to express their opinion clearly without mincing words as the internet serves as coverage for them. The major causes of impoliteness are disappointment at the persona discussed in the article, disagreement and dissatisfaction with the action or opinion of another user. Also, online attacks are more intense as the speaker is shielded by cyberspace. This is evident at the rate at which different users resort to flaming and counter flames. Finally, the rule of syntax and semantics though not emphasized also count. While the choice of words alone cannot ascertain impoliteness, it cannot be completely ruled out. At the same time, effective comprehension is mostly guaranteed when the diversion from traditional rules of grammar is minimal. The implicature of the study shows how net users can be impolite because they are anonymous. They demonstrate absolute freedom of expression which is encouraging as it reveals their true position on issues discussed. However, this could also disrupt effective communication and feedback.

\section{REFERENCES}

1. Herring S, Johnson DA, DiBenedetto T. "This discussion is going too far!. Teaching Modern Foreign Languages: A Handbook for Teachers. 2001:67.

2. Neurauter-Kessels M. Impolite reader responses on British online news sites. Journal of Politeness Research, 2011;7:187-214

3. Herring SC. Computer-mediated discourse. In Schiffrin D, Tannen D, Hamilton HE (Eds), The handbook of discourse analysis (pp 612-627). USA: Blackwell Publishing Ltd. 2003.

4. Culpeper J. Towards an anatomy of impoliteness. Journal of Pragmatics, 1996;25:349-367.

5. Kienpointner M. Varieties of rudeness: Types and functions of impolite utterances. Functions of language. 1997 Jan 1;4(2):251-87.

6. Lachenict 1. Aggravating language: A study of abusive and insulting language. International Journal of Human Communication, 1980;6:607688.

7. Brown P, Levinson SC. Politeness: Some universals in language usage. Cambridge: Cambridge University Press. 1987.

8. Locher MA. Polite behavior within relational work: The discursive approach to politeness.

9. Ai H, Lu X. A web-based system for automatic measurement of lexical complexity. In27th Annual Symposium of the Computer-Assisted Language Consortium (CALICO-10). Amherst, MA. June 2010 Jun 8 (pp. 8-12).

10. Lorenzo-Dus N, Blitvich PG, Bou-Franch P. Online polylogues and impoliteness: The case of postings sent in response to the Obama Reggaeton YouTube video. Journal of Pragmatics. 2011 Aug 1;43(10):2578-93.

11. Pennanen SP. The structure of impolite events in computer mediated conversation: insulting adjectives in comments on a discourse. 2013. Retrieved November 10, 2015 from www.helda.helsinki.fi/bitstream/handle/10138/389 57/thestruc

12. Sproul L, Kiesler S. Connections: New ways of working in the networked organization. Cambridge: MIT Press. 1991.

13. Claridge AW, Seebeck JH, Rose R. Bettongs, potoroos and the musky rat-kangaroo. CSIRO PUBLISHING; 2007.

14. Herring R, inventor; ATX Tech Inc, assignee. System and method for voice and data over digital wireless cellular system. United States patent application US 09/788,158. 2002 Jan 3.

15. Yule G. The study of language. United Kingdom: Cambridge University Press. 1996.

16. Hoffman ML, Saltzstein HD. Parent discipline and the child's moral development. Journal of 
personality and social psychology. 1967 Jan;5(1):45.

17. Primadianti N. A pragmatic analysis of impoliteness in Para-normal movies (Unpublished masters dissertation). Yogyakarta State University, Yogyakarta. 2015. Retrieved November 5, 2015 from

www.epruits.uny.ac.id/17676/1/nabella\%2011211 141035\%20.pdf

18. Goffman E. Interaction ritual: Essays on face-toface behavior. New York: Academic Press. 1967.

19. Brown P, Levinson SC. Universals in language usage: Politeness phenomena. In Goody EN, (ed). Question and Politeness: Strategies in social interaction, 1978;56-311. Cambridge: Cambridge University Press.

20. Dalton EJ. Impoliteness in computer mediated communication (Unpublished masters dissertation). San Diego State University. 2013. Retrieved November 5, 2015 from www.sdsudspace.calstate.edu/bitstream/ha...

21. Terkourafi M. "Towards a unified theory politeness, impoliteness, and rudeness". In D. Bousfield, M. Locher (Eds). Impoliteness in language: Studies on its interplay with power in theory and practice (pp. 45-74). Berlin: Mouton de Gruyter. 2008.

22. O'Driscoll J. "About face: A defence and elaboration of universal dualism", Comparative Literature, 1996;25(1):1-32.

23. Spencer-Oatey H. "(Im) politeness, face and perception of rapport: Unpackaging their bases and interrelationship", Journal of Politeness Research: Language, Behaviour, Culture, 2005;1(1):95-119.

24. Brewer MB, Gardner W. "Who are We? Levels of collective identity and self-representation", Journal of Personality and Psychology, 1996;7(10):83-93.

25. Lakoff G. Some empirical results about the nature of concepts. 1990.

26. Eelen G. A critique of politeness theories. Manchester: St. Jerome's Press. 2001.

27. Culpeper J, Bousfield D, Winchmann A. Impoliteness revisited: With special reference to dynamic and prosodic aspects. Journal of Pragmatics, 2003;35(110-11):1545-1579.

28. Odebunmi A. Pragmatics. In I. Kamalu \& I Tamunobelema (Eds), Issues in the study of language and literature: theory and practice (pp. 196-221). Ibadan: Kraft Books Limited. 2015.

29. Lakoff R. Language and woman's place. Language in society. 1973 Apr;2(1):45-79.
30. Mills S. Gender and politeness. Cambridge: Cambridge University Press. 2003. Retrieved November $\quad 5, \quad 2015$ from www.equinoxpub.com/journal/index.php

31. Watts RJ. Politeness. Cambridge: Cambridge University Press. 2003.

32. Fraser B, Nolen W. The association of deference with linguistic form. International journal of the Sociology of Language. 1981;1981(27):93-110.

33. Leech JA, Ghezzo H, Stevens D, Becklake MR. Respiratory pressures and function in young adults. American Review of Respiratory Disease. 1983 Jul;128(1):17-23.

34. Spencer-Oatey H. Rapport management: A framework for analysis. Culturally speaking: Managing rapport through talk across cultures. 2000;1146.

35. Tracy K, Tracy S. Rudeness at 911: Reconceptualizing face and face attack. Human Communication Research, 1998;25(2):225-251.

36. Culpeper J. Impoliteness and entertainment in the television quiz show: the weakest link. Journal of Politeness Research, 2005;1:35-72.

37. Methias NW. Impoliteness or under politeness: An analysis of a Christian's dinner scene from Dickens Great expectation. Journal of king Saud University, 2009;11-18. Retrieved November 2, 2015 from www.science/rect.com/science/article/

38. Mills CW. "Ideal theory" as ideology. Hypatia. 2005 Jul 1;20(3):165-84.

39. Culpeper J. Conversational impoliteness formulae, Journal of Pragmatics, 2010;42(12):3232-3245.

40. Watts RJ. "Rudeness, conceptual blending theory and relational work". Journal of Politeness Research: Language, Behaviour, Culture, 2008;4(2):289-317.

41. Culpeper J. Impoliteness: Using language to cause offence. Cambridge: Cambridge University Press. 2011.

42. Culpeper J. Reflections on impoliteness, relational work and power. Impoliteness in language: Studies on its interplay with power in theory and practice. 2008 Sep 25;21:17.

43. Bousfield D. Impoliteness in interaction. Armsterdam and Philadelphia: John Benjamins. 2008.

44. Cashman R. The bitter-sweet awakening: The legacy of the Sydney 2000 Olympic Games. Pan Macmillan; 2006.

45. Abbas FN. Linguistic impoliteness and social disruption in literary discourse. International Journal of English and Education, 2012;1(2):180191. 